Introduction of Honorary Fellows

Professor Leon Eisenberg was unable to attend the Annual Meeting in July 1985 and was presented at this meeting.

Professor L. Eisenberg (introduced by Professor I. Kolvin) Professor Leon Eisenberg is renowned for an extraordinary range of accomplishments. He is, to borrow an archaism, the complete psychiatrist.

Leon Eisenberg's considerable promise was recognised at an early stage by one of the founding fathers of modern child psychiatry, Professor Leo Kanner. The qualities Kanner recognised in the young Eisenberg were those of a true intellectual, a superb communicator and an excellent capacity for clinical research. It is true that to a certain extent most of us are moulded by our teachers and it is not surprising that, reared in the invigorating climate of Johns Hopkins, Eisenberg absorbed into his life and work all the strengths of scientific discipline in clinical and research practice. Within a decade, he was a full Professor at Johns Hopkins and a colleague and collaborator of Leo Kanner. This potential was more widely recognised when soon he was elected as Chairman of the Child Psychiatry Section of the American Psychiatric Association. However, the horizons of a sub-specialty proved too narrow for someone of Leon Eisenberg's breadth of vision and ability. When I met him 17 years ago he was in his mid forties and by that time he had been a full Professor for eight years, six of them in Child Psychiatry at Johns Hopkins and two as Professor and Chairman in General Psychiatry at the Massachusetts General Hospital, Boston. By 1980 his immense talent allowed him to switch yet again to become Professor and Chairman of the Social Medicine Department at Harvard University Medical School.

He has been on the editorial board of about a dozen major journals covering child and general psychiatry, psychosomatics, paediatrics and social medicine and for 10 years was the editor of the Journal of Orthopsychiatry. His considerable talent led to great demands on his time from both the World Health Organization and the National Institute of Health and, of course, from many other bodies both in North America and Europe. Despite these many commitments he has over $\mathbf{2 0 0}$ publications, the following themes being particularly prominent: social deprivation; social factors in the major psychoses and mental handicap, psychiatric and general health care and prevention of ill health in different cultures; intelligence, race and class and psychopharmacology. In child psychiatry his interests have been in the psychoses, school phobia, behaviour disorders and hyperkinesis; adolescent problems and suicide. Recently he has shown an interest in the future of psychiatric research.

What about the man himself? Leon Eisenberg has always concerned himself with social and practical issues in his research. Over his career he has tended to identify with socially important but often politically unpopular themes, such as 'Prevention-a political slogan or an attainable goal? He is an exciting personality, always bubbling over with enthusiasm for new ideas. In Boston he has played a major role in integrating the different branches of psychiatry at the Massachusetts General Hospital and Harvard University. In that exercise he has always encouraged a broad eclectic philosophy. Just as his own career was promoted by Kanner, he in turn has heiped to realise the aspirations of the bright trainees who have flocked to sit at his feet and at all times he has proved responsive to their needs. In private one quickly becomes aware of his vast knowledge of the arts and literature. He is one of those lucky individuals who proves to be not only professionally successful but also a marvellous raconteur with a lively sense of humour.

These many qualities and achievements have been honoured in many ways, even in the United Kingdom. He was, for instance, awarded an honorary DSc in Manchester in 1974 and a Burroughs Wellcome Royal Society of Medicine Visiting Professorship in 1982. Recently our College added to these signs of international recognition. The College has welcomed one of the most complete and wise of the leaders of our profession to our Fellowship of Psychiatrists. President, it is with great pleasure I present to you, Professor Leon Eisenberg.

\title{
Annual Elections Honorary Officers and Council
}

Fellows and Members of the College are reminded of their rights in connection with the forthcoming elections for the offices of Dean, Registrar, Treasurer, Editor, Librarian and Sub-Deans. All Honorary Officers except the Treasurer, Dr C. M. B. Pare, who has served seven years, are eligible for re-election.

The nominating meeting of Council will be held on 19 March 1986, and the last date for receiving nominations will therefore be 16 April 1986. Nominations may also be submitted for vacancies for Elected Members of Council. The relevant Bye-Laws and Regulations are printed below.

\section{Extracts from Bye-Laws and Regulations}

Bye-LaW XII THE OTHER HONORARY OFFICERS

1. The Council shall, in accordance with the Regulations, make its nominations for the offices of Dean, Registrar, Treasurer, Editor, Librarian at the first meeting after the name of the President for the next ensuing College year has become known. Written nominations for the above Honorary Offices, accompanied in each case by the nominee's written consent to stand for election, may also be lodged with the Registrar at such time as may be prescribed by the Regulations, provided that each such 
nomination is supported in writing by not less than twelve Members of the College who are not members of the Council.

2. The Dean, Registrar, Treasurer, Editor and Librarian shall be elected from amongst the Fellows by the Members of the College, in each case in accordance with the procedure prescribed by the Regulations.

Regulation XII ELECTION OF THE OTHER HONORARY OFFICERS

1. The method of electing the Honorary Officers other than the President, the Vice-Presidents, and Sub-Deans shall be the same as that for electing the President,* save that nominations from Members of the College who are not members of the Council shall be lodged with the Registrar between the first day of January in any calendar year and the date which is four clear weeks after that meeting of the Council which is the first held after the name of the President for the next ensuing College year has become known, or (as the case may be) which is four clear weeks after that meeting of the Council which, in the case of a

*i.e. Written nominations, accompanied in each case by the nominee's written consent to stand for election, may be lodged with the Registrar, provided that each such nomination is supported in writing by not less than twelve Members of the College who are not members of the Council. An election by ballot shall be held in accordance with the provisions of the Regulations. tie on the second ballot, determines the election of the President.

Regulation XIX THE COUNCIL

3. Not less than four of the twelve elected members of Council shall be elected or re-elected each year, subject to the overall condition that no elected member shall serve on Council for more than six years in that capacity without a break of at least one year. At its first meeting in each College year after the name of the President for the next ensuing College year has become known, the Council shall nominate for election to the Council four or more members of the College. Any nominee who is proposed and seconded and gives his consent in writing to serve shall be validly nominated. Any twelve Members of the College may make nominations in writing at any time between the first day of January in each year and the date which is four clear weeks after the meeting of the Council at which its nominations are made. Nominations other than those made by the Council shall be lodged with the Registrar and accompanied by the written consent of the candidate to serve if elected. Should there be more nominations than vacancies, an election shall be held by ballot of the Members of the College. The ballot paper shall not indicate the method of nomination or the names of those nominating. If the number of nominees does not exceed the number of vacancies, these nominees shall be declared elected at the first meeting, whether of the Council or of the Executive and Finance Committee, after the expiry of the period of four clear weeks in this paragraph referred to.

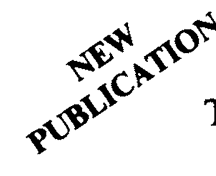

\title{
GASKELL
}

The Publications Section of the Royal College of Psychiatrists CONTEMPORARY ISSUES IN SCHIZOPHRENIA

Edited by Alan Kerr and Philip Snaith

\author{
ISBN 0902241141 \\ $\operatorname{Pp} 480$ \\ $£ 17.50$ \\ $£ 15.00$ (special pre-publication price) to Fellows, Members and Inceptors
}

This book presents a comprehensive selection of re-edited papers published in the British Journal of Psychiatry during the last ten years, together with a number of specially commissioned reviews of current knowledge in schizophrenia. The subject is considered under seven sections: general and historical concepts; classification and phenomenology; organic aspects; genetic aspects; social aspects; treatment; and outcome.

Contemporary Issues in Schizophrenia will be published in February 1986 at $£ 17.50$, postage free to non-members but Fellows, Members and Inceptors of the Royal College of Psychiatrists may buy it at the special pre-publication price of $£ 15.00$. postage free. Orders and cheques should be sent to: Editorial Office, Royal College of Psychiatrists, 17 Belgrave Square, London SW1X 8PG. 